\title{
Job Involvement as Predictor of Employee Commitment: Evidence from Pakistan
}

\author{
Tariq Iqbal Khan \\ PhD Candidate, Mohammad Ali Jinnah University, Islamabad, Pakistan \\ Tel: 92-322-454-4815 E-mail: t_i_khan@hotmail.com \\ Farooq Ahmed Jam \\ Faculty of Management Studies, University of Central Punjab, Lahore, Pakistan \\ Tel: 92-333-221-3269 E-mail: jam_farooq@yahoo.co.uk
}

Aisha Akbar

Faculty of Social Sciences, Muhammad Ali Jinnah University, Islamabad, Pakistan

Tel: 92-323-549-9040Ｅ-mail: aakbar@jinnah.edu.pk

Muhammad Bashir Khan

Faculty of Management Sciences, Iqra University, Islamabad, Pakistan

Tel: 92-300-909-0919Ｅ-mail: drmohdbashir@hotmail.com

Syed Tahir Hijazi

Professor Dr. (Pro-rector) at University of Central Punjab Lahore, Pakistan

Tel: 92-300-856-6436_E-mail: hijazisyed@yahoo.com

Received: September 1, $2010 \quad$ Accepted: October 15, $2010 \quad$ doi:10.5539/ijbm.v6n4p252

\begin{abstract}
Job involvement has been one of the most effective tools used for increasing employee productivity by enhancing employee participation and commitment. This study highlights the effect of job involvement on three types of commitments i.e. affective commitment, Continuance commitment and normative commitment. Data was collected from 211 employees of 11 different organizations and analysis revealed that job involvement has positive impact on three types of commitments.
\end{abstract}

Keywords: Job involvement, Employee commitment, Employees participation, Job characteristics, Job design, Affective commitment, Normative commitment, Continuance commitment

\section{Introduction}

Job Involvement and its outcomes such as job satisfaction, job commitment, and employee job performance are among the most studied areas in organizational behavior and human resource management research. Job involvement is defined as the measure of the degree to which employee is involved in his job and takes part in decision-making. Employees' job involvement increases if employees have decision making authority, responsibility and the tempo of the work (Bass, 1965).

Paullay, Alliger and Stone-Romero (1994) defined the job involvement as "The degree to which one is cognitively preoccupied with, engaged in, and concerned with one's present job"'(p. 225). It is one of the key factors of employee's empowerment and employee's participation in decision making. Involvement in decision-making and other related matters of one's job can enhance the performance of employee. It also creates 
the sense of ownership in employees who are involved in decisions regarding their job and its related activities.

Researchers showed the great interest in employee, involvement practices and their outcomes (Fenton-O'Creevy and Nicholson, 1994). Involvement in work and alienation from work effect the standard of one entire's life experience (Argyris, 1964; Levinson, 1976).

\section{Literature Review}

\subsection{Job Involvement}

First Lodahl and Kejner (1965) presented the phenomenon of job involvement by discussing various data about the impact of job design elements on job involvement. Job involvement is important element that has significant impact on individual employee and organizational outcomes (Lawler, 1986). Li and Long (1999) define job involvement as degree to which one show emotional or mental identification with his job.

Job involvement can be elaborated that it is engagement regarding the internalization of values about the righteousness of work or the significance of work in the value of the individual (Lodahl \& Kejner, 1965). This shows that researchers are working on this long ago and many organizations have applied the research findings. Most of the researchers are agreed on this fact that job involvement is different construct from other associated constructs which includes organizational commitment, job satisfaction and intrinsic motivation (Shore, Thornton \& Shore, 1990; Patterson \& O'Driscoll, 1990; Brooke, Russell \& Price, 1988; Dolke \& Srivastara, 1988; Blau, 1986).

Reitz and Jewell (1979) said that job involvement is linked to importance of work in individual's routine or daily life .This mean if one gives importance to his work certainly he is loyal to his work as well as to the organization. This will also affect the performance of individual. In addition, Gurin, Veroff, and Feld (1960) also sighted involvement as the extent to which performance have an effect on one's self-esteem. Job factors can influence the involvement level of individual in his job (Vroom, 1962). Lawler and Hall (1970) in this regard proposed that most practical sight of job involvement might be role of job and individual relationship. Both individual's own personality and variables influenced by different situations can change the level of job involvement (Rabinowitz \& Hall, 1977).

The employees whose involvement in job is high can be said that the job is important to individual's self-image (Kanungo, 1982). Job involvement is very low among part time employees and research shows that job involvement in full time employees are higher than the part time or contractual employees (Martin \& Hafer, 1995). It can be said that employees are involved in their job if they enthusiastically take part in the job related matters (Allport, 1943), they see job as most important and significant part in life (Dubin, 1966), and recognize performance as main feature of their self-worth (Gurin et al., 1960). This means that job involvement has major impact on productivity and efficiency of employee and work has vital role in increasing job involvement of individual if it plays significant role in the life of employee. (Probst \& Tahira, 2000).

Lawler (1986) sees job involvement as significant key factor for creating and increasing motivation of employees in view of organization and motivation play important role in productivity and performance of individual. If we see job involvement from the view of individual it may be believed as significant to individual's own growth and satisfaction within the work environment as well as motivation and attitude directed to goal (Hackman \& Lawler, 1971; Kahn, 1990; Lawler \& Hall, 1970).

Management should understand the importance of job involvement because it is most important and essential component of work behavior among the workforce as prior research proved this phenomenon (Manojlovich, Laschinger, \& Heather, 2002; Soong, 2000). It was highlighted that by giving employees power over their work content i.e. decision regarding swiftness of work ,quality of product and job related abilities and resources can motivate the employees to enhance their job involvement.

(Hackman \& Oldham 1975, 1976, 1980), proposed in their job characteristics model (JCM) that features of job can affect the job involvement because these features may encourage the internal motivation of employees. In other words, goodness and significance of work play important role in the worth of employee due to internalization of value through job involvement (Lodahl \& Kejner, 1965). Other researchers Lawler (1992) and Pfeffer (1994) also argued that through job design, job involvement could be increased. Employees with significantly high job involvement considered and recognized by their job and job play an important role in their routine lives (Sonnentag \& Kruel, 2006) i.e. job is more important for their lives from anything else.

Individuals or employees may be involved in their job even in the temporarily and non-natural situation of laboratory (Lewis, 1944; Lewis \& Franklin, 1944). This clearly indicates the role of work and job design in enhancing job involvement. It is also clear that employees with high job involvement are more self-determining 
and self-assured (Wood, 1974). Job involvement can be linked to decision-making and decision to produce (March \& Simon, 1958).

The researchers found negative relationship between job stressors and job involvement i.e. employees whose job involvement is high respond more negatively to job stressors (Frone, Russell, \& Cooper, 1995).

In addition, job involvement is considered as opposite of perception of alienation (Argyris, 1964; Kanungo, 1979, 1982) and job involvement has significant relation with turnover (Bass, 1965). It has been observed that job involvement has negative relationship with threat of job insecurity, in other words if highly involved individual perceive the threat of job insecurity ,he will react more negatively (Greenhalgh and Rosenblatt, 1984) as compared to those whose level of involvement is low. Most researchers used job involvement as forecaster for turnover and absenteeism. In this regard, they also used combination of job involvement and organizational commitment for predicting turnover and absenteeism (Brown, 1996). However, before three-decades job involvement received little importance regarding relationship with absenteeism (Randall \& James, 1980), while empirical research found negative relationship between job involvement and absenteeism (Rabinowitz \& Hall, 1977). If we go further back Hackman and Lawler (1971) took the sample of 208 employees of telephone company, where they found frequency of absenteeism linked to job involvement as $(r=-0.15, \mathrm{p}<.05)$ and no job involvement relationship found by (Siegel \& Ruh, 1973). However, in previous studies (Mathieu \& Zajac, 1990) the issue of discriminant validity has been raised and variables of job satisfaction, job involvement and organizational commitment found to be always associated and correlated to each other. Consequently, other researchers Brooke et al. (1988) and Mathieu and Farr (1991) also carried out the investigations in which they found discriminant validity for job involvement, organizational commitment, and job satisfaction and also found that all three variable are different concepts and ideas.

Reviewing several studies related to job involvement and organizational commitment revealed correlations of $(r=0.50)$ between job involvement and job satisfaction, job satisfaction and organizational commitment and correlation between organizational commitment and job involvement (Cheloha \& Farr, 1980; Gechman \& Wiener, 1975; Hall \& Schneider, 1972; Mowday, Porter \& Steers,1982; Mowday, Steers, \& Porter, 1979; Rabinowitz \& Hall, 1977; Weissenberg \& Gruenfeld, 1968; Wood, 1974).

\subsection{Organizational Commitment}

Becker's (1960) "side-bets" theory originated the concept of commitment and defined commitment as "consistent lines of activity". Organizational commitment also been defined as recognition with and devotion to the concerned organization and its targets (Blau \& Boal, 1987).

Considerable work has been done on organizational commitment by researchers who are in the field of organizational behavior during last few decades (Benkhoff, 1997; Mathieu \& Zajac, 1990). The focus of organizational commitment is on individual employee and it highlights the extent to which one identifies with and deeply involved in with organization (Porter, Steers, Mowday \& Boulian; 1974). Researchers also worked on different aspects of commitment during last several years (Fukami \& Larsen, 1984; Morrow, 1983; Reichers, 1985).

Meyer and Allen (1991) and Allen and Meyer (1990) suggested three forms of commitment affective commitment, continuance commitment, and normative commitment.

Meyer and Allen (1984, p. 69, 372-378) define these aspects as under:

(1) Affective commitment as "an employee's emotional attachment to, identification with, and involvement in the organization". As per Morrow (1983) affective organizational commitment is more dependent on characteristics of job rather than personal characteristics this mean that it is less concerned with extrinsic factors rather than intrinsic factors.

(2) Continuance commitment as "commitment based on the costs that employees associate with leaving the organization".

(3) Normative commitment as "an employee's feelings of obligation to remain with the organization".

As per arguments of Meyer and Allen (1991) we can only understand the nature of relationship of individual with organization when all above mentioned types of commitment studied and considered together, because each type of commitment has its own results and affects on the behavior of individual during the job and furthermore each type has its own implications. On the job behavior and job performance might be different if linked with three types of commitment i.e. affective, continuance, and normative commitment Meyer and Allen (1991). It has been observed by different research scholars that Affective, Continuance and Normative Commitment Scales 
measure comparatively different constructs (Allen \& Meyer, 1990; Hackett, Bycio, \& Hausdorf, 1992; McGee \& Ford, 1987; Meyer, Allen, \& Gellatly, 1990; Shore \& Tetrick, 1991). It is very important that researchers (e.g., Becker, 1992; Darden, Hampton, \& Howell, 1989; Reichers, 1986; Steffy \& Jones, 1988) begin to give importance to dual or various types of commitment and impact of these commitments.

Organizational commitment is very important for organizations because of the desire to retain talented employees. Employees with high organizational commitment spend more personal resources during the job for the organization and also retain with organization and will not remain in search of other employment (Bret, Corn \& Slocum, 1995).

Those employees who are not satisfied with their job perceived threat of job security and switch or quit the job, in this case they are also less committed towards the organization they are working for. Researchers remain keen to know the outcomes of organizational commitment since long (Davy, Kinicki, \& Scheck, 1991). Morrow (1983, 1993) clarified the different aspects and features through which employees may be committed.

In another study Meyer, Paunonen, Gellatly, Goffin, \& Jackson, (1989) while referring to performance and commitment of first line managers found the positive relationship between affective commitment and job performance and negative correlation between continuance commitment and job performance. Studies in literature argued and confirmed that job involvement and employee commitment has significant relationship (Janis, 1989; Loui, 1995; Brown, 1996). Job involvement and organizational commitment both are linked with identification and recognition of employee with his work and job experience, in this aspect of job both are similar to some extent ( Chughtai, 2008). Many studies found job involvement and job commitment alike in various aspects (Lodahl \& Kejner, 1965; Rabinowitz \& Hall, 1977), but job commitment may be assess as dedication that employees believe or perceive towards particular work and job they carried out in the organization. Brown (1996) also found very close relationship between job involvement and organizational commitment and consider organizational commitment as outcome of job involvement. However both phenomena are different in various aspects that job involvement is link and recognition of individual's instant and current activities while organizational commitment is found to be the attachment of individual with organization (Brown, 1996). A study conducted in the similar context found positive relationship between job stress and organizational commits, affective commitment and continuance commitment, while this positive relationship was not confirmed for normative commitment (Ziauddin, Khan, Jam \& Hijazi, 2010).

Mowday et al. ( 1982 ) in their study confirmed that in many situations primarily employees be acquainted with and involved in specific job , this activity make them satisfied due to fulfillment of psychological wants and needs and their commitment toward organization develops.

Employee job involvement has significant relationship with employee commitment. Employees who have high level of job involvement and organizational commitment are the more motivated than those who have low level of job involvement and organizational commitment, because they are fascinated by both job and organization (Blau \& Boal, 1987). Job involvement and commitment both have significant impact on organizational and individual performance. If individual is involved in his job, he will probably be satisfied with job and committed to the organization (Knoop \& Robert, 1995).

Perspective of financial need (Gould \& Werbel, 1983) regarding job involvement and organization commitment been studied by different researcher. Research on job involvement and organizational commitment on nurses showed that both have important predictors of unconstitutional tardiness and absence (Blau, 1986) .A study was replicated by Mathieu and Kohler (1990) in which they took the sample of 192 drivers of one of Public Sector Company and found relationship between job involvement and organizational commitment as predictor of absence from job. The employees who have high job involvement and organizational commitment, their level of voluntary absence is low. Blau and Boal (1987) also presented a theoretical model in which they described interaction of job involvement and organizational commitment on turnover and absence attitude. All above literature shows that organizational commitment and job involvement are experientially different concept and showed diverse features of attachment related to work (Ulrika \& Willmar, 2006).

\subsection{Hypothesis}

On the basis of literature following Hypotheses were developed:

Hypothesis 1. Employee job involvement is positively related to Affective commitment.

Hypothesis 2. Employee job involvement is positively related to Continuance commitment.

Hypothesis 3. Employee job involvement is positively related to normative commitment. 


\section{Methodology}

\subsection{Sample}

Sample for this study was 211 from 11 different organizations .Following scales were used to measure different variables:

\subsection{Measures}

3.2.1 Job involvement: used ten-item job involvement scale developed by Kanungo (1982). Example of items used was "The most important things that happen to me involve my present job". The alpha reliability was found $(\alpha=80)$ for 10 items of job involvement.

3.2.2 Employee Commitment: Employee commitment (Affective, continuance and normative commitment) was measured by using Allen and Meyer's (1990) scale. The alpha reliability were found $(\alpha=.70)$ for affective commitment, $(\alpha=.67)$ for continuance commitment and $(\alpha=.67)$ for normative commitment.

\subsection{Data Collection}

Data was collected through personally administered questionnaires. For this purpose, data was collected from 11 different public and private sector organizations. Total 260 questionnaires were distributed and 228 questionnaires (response rate of $87.6 \%$ ) filled in were received back. Among 228 questionnaires, 211 questionnaires found completely filled in by all aspects. So useable sample data was 211 with response rate of $81 \%$. Questionnaires were distributed and filled in by those employees whose level of education is graduation and above. The mean age of respondents was 30.37 years with standard deviation of 7.27. All responses were taken on like scale of 5 starting from strongly disagree to the strongly agree .Representation of theses measure were as under:

$1=$ strongly disagree, $2=$ Disagree, $3=$ neither disagree nor agree, $4=$ Agree, and $5=$ strongly agree

All constructs were obtained through self-reported measure of respondents.

\subsection{Control Variables}

Age, gender, and current tenure were used as control variables in the present study. Previous research shows that these variables can predict a variety of job outcomes such as job satisfaction, job performance, employee's commitment, stress and so on.

Insert Figure 1 here

\section{Results}

Descriptive statistics are shown in Table 1. This table shows the means and standard deviations of variables. Mean of independent variable job involvement was found to be $3.36(\mathrm{~S} . \mathrm{D}=0.66)$ and mean for affective commitment was $3.45(\mathrm{~S} . \mathrm{D}=0.73)$, continuous commitment $3.28(\mathrm{~S} . \mathrm{D}=0.64)$, normative commitment 3.33(S. $\mathrm{D}=0.64)$.

The frequencies were calculated to test the normality of data and found that data used in present research was normally distributed.

Insert Table 1 here

Correlation values among independent variable and outcome are shown in Table 2. In this table, we analyzed the three types of employee commitment separately to clarify their affect independently. Job involvement showed the positive relationship with affective commitment $(\mathrm{r}=.59 p<.01)$. The relationship between job involvement and continuous commitment found positive $(\mathrm{r}=.34, \mathrm{p}<.01)$. Job involvement had showed the positive relationship with normative commitment $(\mathrm{r}=.59 p<.01)$. These results proved hypothesis true that job involvement is positively related to affective commitment, continuous commitment and normative comr snt.

Insert Table 2 here

\section{Regression Analysis}

Regression was run to test/verify the significance level of job involvement with dependent variables.

Table 3 shows the regression result of job involvement and affective commitment. These finding confirmed the significant relationship between job involvement and affective commitment $(\beta=.59, \mathrm{p}<.001)$. 
In Table 4 regression was run to test the significance between job involvement and continuous commitment .Results showed that job involvement has significantly positive relationship with continuous commitment $(\beta=.33 \mathrm{p}<.001)$.

Insert Table 4 here

Table 5 shows the result of regression regarding job involvement and normative commitment. Job involvement is significant positive relationship with normative commitment $(\beta=.56, \mathrm{p}<.001)$.

Insert Table 5 here

\section{Conclusion and Discussion}

The importance of job involment in human resource management and organizational behavior research is proved due to its clear and significant linkages with outcomes such as job performance, job satisfaction, organizational citizenship behavior, job stress turnover intention and organizational commitment. While on the other hand organizational commitment is considered very important outcome for the individual and organizational performance. The objective of this study was to replicate the job involvement and organizational commitment relationship in Pakistani context. Unique context is the major strength of this study. The results of the study revealed that all the hypothesis developed in this research study got significant support and proved that job involvement is positively related to affective commitment $(\beta=.59, \mathrm{p}<.001)$, continuance commitment $(\beta=.33$ $\mathrm{p}<.001)$ and normative commitment $(\beta=.56, \mathrm{p}<.001)$. These findings and consistent with the finding of Brown (1996) that organizational commitment is an outcome of job involvement. Other researchers (Tansky, Gallagher \& Wetzel, 1997; Cohen, 1999) also confirmed this relationship of job involvement and organizational commitment. Overall study proved the significance of job involvement with employee commitment. This clearly indicates that those organizations that have job involvement culture, their employees are more committed with organization than those organizations who do not involve their employees. This notion is now proved with the evidence from Pakistan.

\section{Managerial Implications and Future Research Directions}

The practitioners and human resource managers can get insight from the findings of this study that organizational commitment can be increased through keeping the employees involved in their jobs. It will not only increase the organizational commitment but indirectly or directly it will affect several other outcomes associated with job involvement and commitment. It will increase the OCB, creativity, job satisfaction, employee's in-role performance and it will decrease job stress, turnover intention of the employees. Human resource managers and organizational development practitioners should focus on the culture, design and environmental factors which foster the job involvement of the employees.

Future research should look at the different mediators and moderator involved in job involvement and outcomes relationship. Job involvement study is recommended with other outcomes such as creativity, burnout, turnover intention, psychological contract breach and cynicism. A longitudinal study is recommended to test the findings of our study in different context.

\section{References}

Allen, N. J., \& Meyer, J. P. (1990). The measurement and antecedents of affective, Continuance and normative commitment. Journal of Occupational Psychology, 63, 1-18.

Allport, G. (1943). The ego in contemporary psychology. Psychological Review, 60, 757-760.

Angle, L., \& Perry, L. (1983). Organizational Commitment: Individual and Organizational Influence. Work and Occupation, 10(2), 123-146.

Argyris, C. (1964). Integrating the individual and the organization. New York: Wiley.

Ashford, S., Lee, C., \& Bobko, P. (1989). Content, causes, and consequences of job insecurity: A theory-based measure and substantive test. Academy of Management Journal, 32, 803-829.

Bass, B. M. (1965). Organizational psychology. Boston: Allyn \& Bacon.

Becker, H. S. (1960). Notes on the concept of commitment. American Journal of Sociology, 66, 32-42.

Becker, T. E. (1992). Foci and bases of commitment: Are they distinctions worth making? Academy of Management Journal, 35, 232-244.

Benkhoff, B. (1997). Ignoring commitment is costly: New approaches establish the missing link between commitment and performance. Human Relations, 50, 701-726. 
Blau, G. J. (1986). Job involvement and organizational commitment as interactive Predictors of tardiness and absenteeism. Journal of Management, 12, 577- 584.

Blau, G. J., \& Boal, K. R. (1987). Conceptualizing how job involvement and organizational commitment affect turnover and absenteeism. Academy of Management Review, 12, 288-300.

Blau, P. M. (1964). Exchange and power in social life. New York: Wiley.Blauner, R. (1964). Alienation and freedom. Chicago: University of Chicago Press.

Bret, J. F., Corn, W. L., \& Slocum, J. W. Jr. (1995). Economic dependency of work: A Mediator of the relationship between organizational commitment and Performance. Academy of Management Journal, 38, 261 271.

Brooke, P.P., Russell, D.W., \& Price, J.L. (1988). Discriminant validation of measures of Job satisfaction, job involvement and organization commitment. Journal of Applied Psychology, 73, 139-145.

Brown, S.P. (1996). Ameta-analysis and review of organizational research on job involvement. Psychological Bulletin, Vol.120, pp.235-55.

Cheloha, R. S., \& Farr, J. L. (1980). Absenteeism, job involvement and job satisfaction in an organizational setting. Journal of Applied Psychology, 65, 467-473.

Chughtai, A. A. (2008). Impact of Job Involvement on In-Role Job Performance and Organizational Citizenship Behavior. Journal of Behavioral and Applied Management.

Cohen, A. (1999). Relationships among five forms of commitment: An empirical Assessment. Journal of Organizational Behavior, 20, 285-308.

Darden, W. R., Hampton, R., \& Howell, R. D. (1989). Career versus organizational commitment: Antecedents and consequences of retail salespeople' commitment. Journal of Retailing, 65, 80-106.

Davy, J., Kinicki, A., \& Scheck, C. (1991). Developing and testing a model of survivor responses to layoffs. Journal of Vocational Behavior, 38, 302-317.

Dolke, A.M., \& Srivastara, P.K. (1988). Need satisfaction, job involvement and intrinsic motivation: A factor analytic study. Indian Journal of Applied Psychology, 25, 13-17.

Dubin, R.J. (1966). Industrial worker's world: A study of the central life interest of industrial workers. Social Problems, 3, 131-142.

Fenton-O'Creevy, M., and Nicholson, N. (1994). Middle Managers: Their Contribution to Employee Involvement. Employment Department Research Series, No. 28.

Fisher, C., \& Gitelson, R. (1983). A meta-analysis of the correlates of role conflict and role ambiguity. Journal of Applied Psychology, 68, 320-333.

Frone, M. R., Russell, C. J., \& Cooper, M. L. (1995). Job stressors, job involvement and employee health: A test of identity theory. Journal of Occupational and Organizational Psychology, 68, $1-11$.

Fukami, C. V., \& Larsen, E. W. (1984). Commitment to company and union: Parallel laodeh. Journal of Applied Psychology, 69, 367-371.

Gechman, A. S., \& Wiener, Y. (1975). Job involvement and satisfaction as related to mental health and personal time devoted to work. Journal of Applied Psychology, 60, 521-523.

Gordon, M. E., \& Ladd, R. T. (1990). Dual allegiance: Renewal, reconsideration, and recantation. Personnel Psychology, 43, 37-69.

Gould S., \& Werbel, J. (1983). Work involvement--A comparison of dual wage earner and single wage earner families. Journal of Applied Psychology, 68, 313-319.

Greenhalgh, L., \& Rosenblatt, Z. (1984). Job insecurity: Toward conceptual clarity. Academy of Management Review, 9, 438-448.

Gurin, G., Veroff, J., \& Feld, S. (1960). Americans view their mental health. New York: Basic Books.

Hackett, R. D., Bycio, P., \& Hausdorf, P. (1992). Further assessment of a three-component model of organizational commitment. Academy of Management Best Paper Proceedings. pp. 212-216.

Hackman, J. R., \& Oldham, G. R. (1975). Development of the job diagnostic survey. Journal of Applied Psychology, 60, 159-170. 
Hackman, J. R., \& Oldham, G. R. (1976). Motivation through the design of work: Test of a theory. Organizational Behavior and Human Performance, 16, 250-279.

Hackman, J., \& Lawler, E. (1971). Employee reactions to job characteristics. Journal of Applied Psychology, 52, 259-286. (Monograph).

Hackman, J., \& Oldham, G. (1980). Work redesign. Reading, MA: Addison-Wesley.

Hall, D. T., \& Schneider, B. (1972). Correlates of organizational identification as a function of career pattern and organizational type. Administrative Science Quarterly, 17, 340-350.

Huselid, M. A., \& Day, N. E. (1991). Organizational commitment, job involvement, and turnover: A substantive and methodological analysis. Journal of Applied Psychology, 76, 380-391.

Janis, N.A. (1989). Organizational commitment, career factors and career/life stage. Journal of Organizational Behaviour, 10, 247-266.

Kahn, W. A. (1990). Psychological conditions of personal engagement and disengagement at work. Academy of Management Journal, 33, 692-724.

Kanungo, R. (1982). Work alienation: An integrative approach. New York: Praeger.

Kanungo, R. N. (1979). The concepts of alienation and involvement revisited. Psychological Bulletin, 86, $119-138$.

Kanungo, R. N. (1982). Measurement of job and work involvement. Journal of Applied Psychology, 67, 341 349.

Knoop \& Robert, (1995). Relationships among job involvement, job satisfaction, and organizational commitment for nurses. Journal of Applied Psychology, Nov 95, Vol. 129, Issue 6.

Lawler, E. E., III. (1992). The ultimate advantage: Creating the high-involvement organization. San Francisco: Jossey-Bass.

Lawler, E. E., Ill, \& Hall, D. T. (1970). Relationship of job characteristics to job involvement, satisfaction, and intrinsic motivation. Journal of Applied Psychology, 54, 305-312.

Lawler, E.E. (1986). High-Involvement Management, Jossey Bass, SanFrancisco, CA. Management Journal, Vol.33, Pp.692-724.

Levinson, H. (1976). Psychological man. Cambridge, MA: Levinson Institute.

Lewis, H. B. (1944). An experimental study of the role of the ego in work. I. The role of the ego in cooperative work. Journal of Experimental Psychology, 34, 113-126.

Lewis, H. B., \& Franklin, M. (1944). An experimental study of the role of the ego in work. The significance of task-orientation in work. Journal of Experimental Psychology, 34, 195-215.

Li Ye, \& Long Lirong. (1999). A literature review on job involvement. Social Psychological Research, (4): 57-63 (in Chinese).

Lodahl TM, Kejner M. (1965). The definition and measurement of job involvement. Journal of Applied Psychology, 49: 24-33.

Loui, K. (1995). Understanding employee commitment in the public organization: A study of the juvenile detention center. International Journal of Public Administration, 18, 1269-1295.

Manojlovich, M., Laschinger, S., \& Heather, K. (2002). The relationship of empowerment and selected personality characteristics to nursing job satisfaction. Journal of Nursing Administration, 32(11), 586-595.

March, J G., and Simon, H A. (1958). Organization. New York: Wiley.

Martin TN, \& Hafer JC. (1995). The multiplicative interaction effects of job involvement and organizational commitment on the turnover intentions of full- and part-time employees. Journal of Vocational Behavior, 46: 310-331.

Mathieu, J. E., \& Farr, J. L. (1991). Further evidence for the discriminant validity of measures of organizational commitment, job involvement, and job satisfaction. Journal of Applied Psychology, 76, 127-133.

Mathieu, J. E., \& Kohler, S. S. (1990). A test of the interactive effects of organizational commitment and job involvement on various types of absence. Journal of Vocational Behavior, 36, 33-44.

Mathieu, J. E., \& Zajac, D. (1990). A review and meta-analysis of the antecedents, correlates, and consequences 
of organizational commitment. Psychological Bulletin, 108, 171-194.

McGee, G. W., \& Ford, R. C. (1987). Two (or more?) dimensions of organizational commitment: Reexamination of the Affective and Continuance Commitment Scales. Journal of Applied Psychology, 72, 638-641.

Meyer, J. P., \& Allen, N. J. (1991). A three component conceptualization of organizational commitment. Human Resource Management Review, 1, 61-89.

Meyer, J. P., Allen, N. J., \& Gellatly, I. R. (1990). Affective and continuance commitment to the organization: Evaluation of measures and analysis of concurrent and time-lagged relations. Journal of Applied Psychology, 75, 710-720.

Meyer, J. P., Paunonen, S. V., Gellatly, I. R., Goffin, R. D., \& Jackson, D. N. (1989). Organizational commitment and job performance: It's the nature of the commitment that counts. Journal of Applied Psychology, $74,152-156$.

Meyer, J.P \& Allen, N.J. (1984). Testing the "side-bet theory" of organizational commitment: Some methodological considerations. Journal of Applied Psychology, 69, 372-378.

Morrow, P. C. (1983). Concept redundancy in organizational research: The case of work commitment. Academy of Management Review, 8, 486-500.

Morrow, P. C. (1993). The theory and measurement of work commitment. Greenwich, CT: JAI Press.

Mowday, R. T., Porter, L. W., \& Steers, R. M. (1982). Employee-organization linkages: The psychology of commitment, absenteeism and turnover. New York: Academic Press.

Mowday, R.T., Steers, R.M., and Porter, L.W. (1979). The measurement of organizational commitment. Journal of Vocational Behavior, Vol.14, pp.224-47.

Patterson, J.M., \& O'Driscoll, M.P. (1990). An empirical assessment of Kanungo's 1982 concept and measure of job involvement. Applied Psychology in International Review, 30(3), 293-301.

Paullay, I., Alliger, G., and Stone-Romero, E. (1994). Construct validation of two instruments designed to measure job involvement and work centrality. Journal of Applied Psychology, Vol. 79, pp. 224-8.

Pfeffer J. (1994). Competitive Advantage through People: Unleashing the Power of the Work Force. Harvard Business School Press: Boston.

Porter LW, Steers RM, Mowday RT, \& Boulian PV. (1974). Organizational commitment, job satisfaction and turnover among psychiatric technicians. Journal of Applied Psychology, 59(5):603-9.

Probst \& Tahira.M. (2000). Wedded to the job: Moderating effects of job involvement on the consequences of job insecurity. Journal of Occupational Health Psychology, 1076-8998, Vol. 5, Issue 1

Rabinowitz, S., \& Hall, D. P. (1977). Organizational research on job involvement. Psychological Bulletin, 84, 265-288.

Randall S. Cheloha and James L. Farr. (1980). Absenteeism, Job Involvement, and Job Satisfaction in an Organizational Setting. Journal of Applied Psychology, Vol. 65, No. 4, 467-473.

Reichers, A. E. (1985). A review and re-conceptualization of organizational commitment. Academy of Management Review, 10, 465-476.

Reichers, A. E. (1986). Conflict and organizational commitments. Journal of Applied Psychology, 71, 508-514.

Reitz, H. J., \& Jewell, L. N. (1979). Sex, locus of control, and job involvement a six-country investigation. Academy of Management Journal, 22(1), 72-88.

Shore, L. M., \& Tetrick, L. E. (1991). A construct validity study of the survey of perceived organizational support. Journal of Applied Psychology, 76, 637-643.

Shore, T.H., Thornton, G.C., \& Shore, L.M. (1990). Distinctiveness of three work attitudes: Job involvement, organization commitment, and career saliences. Psychological Reports, 67, 851-858.

Siegel, A., \& Ruh, R. (1973). Job involvement, participation in decision making, personal background and job behavior. Organizational Behavior and Human Performance, 9, 318-327.

Sonnentag, S., \& Kruel, U. (2006). Psychological detachment from work during off-job time: The role of job stressors, job involvement, and recovery-related self-efficacy. European Journal of Work and Organizational Psychology, 15(2), 197-217. 
Soong, S. W. (2000). The study on the devotion and job satisfaction of adults' participation in volunteer services. Taiwan: National Kaohsiung Administration, Normal University.

Steffy, B. D., \& Jones, J. W. (1988). The impact of family and career planning variables on the organizational, career, and community commitment of professional women. Journal of Vocational Behavior, 32, $196-212$.

Tansky, J. W., Gallagher, D. G., \& Wetzel, K. W. (1997). The effects of demographics, work status, and relative equity on organizational commitment: Looking among part-time workers. Canadian Journal of Administrative Sciences, 14, 315-326.

Ulrika E. Hallberg and Wilmar B. Schaufeli (2006). "Same Same” But Different? Can Work Engagement Be Discriminated from Job Involvement and Organizational Commitment? European Psychologist, Vol. 11(2):119-127.

Vroom, V. (1962). Ego-involvement, job satisfaction, and job performance Personnel Psychology, 15, $159-177$.

Weissenberg, P., \& Gruekfeld, L. W. (1968). Relationship between job satisfaction and job involvement Journal of Applied Psychology, 52, 469-473.

Wood, D. A. (1974). Effects of worker orientation differences on job attitude correlates. Journal of Applied Psychology, 59, 54-60.

Ziauddin, Khan .M.R., Jam. F.A., and Hijazi. S.T. (2010). The Impact of Job Stress on Organizational Commitment. European Journal of Social Sciences, Vol, 13, 4.

Table 1. Descriptive Statistics

\begin{tabular}{|c|l|c|c|c|c|c|}
\hline S.No. & \multicolumn{1}{|c|}{ Variables } & N & Minimum & Maximum & Mean & S.D \\
\hline 1 & Age & 211 & 20 & 72 & 30.37 & 7.27 \\
\hline 2 & Gender & 211 & 1 & 2 & 1.12 & 0.32 \\
\hline 3 & Ten. Current & 211 & 1 & 38 & 3.80 & 4.98 \\
\hline 4 & Job involvement & 211 & 1.1 & 4.8 & 3.36 & 0.66 \\
\hline 5 & Affective Commitment & 211 & 1 & 5 & 3.45 & 0.73 \\
\hline 6 & Continuous Commitment & 211 & 1.67 & 4.83 & 3.28 & 0.64 \\
\hline 7 & Normative Commitment & 211 & 1 & 4.83 & 3.33 & 0.64 \\
\hline
\end{tabular}

Table 2 .

\begin{tabular}{|c|l|r|r|r|r|r|r|r|r|r|}
\hline $\mathbf{S . \#}$ & Variables & $\mathbf{1}$ & $\mathbf{2}$ & $\mathbf{3}$ & $\mathbf{4}$ & $\mathbf{5}$ & $\mathbf{6}$ & $\mathbf{7}$ & $\mathbf{8}$ & $\mathbf{9}$ \\
\hline $\mathbf{1}$ & Gender & & & & & & & & & \\
\hline $\mathbf{2}$ & Age & $-.24^{* *}$ & & & & & & & & \\
\hline $\mathbf{3}$ & Tenure current & -.07 & $.58^{* *}$ & & & & & & & \\
\hline $\mathbf{4}$ & Job involvement & -.01 & $.16^{*}$ & $.14^{*}$ & $\mathbf{. 8 0}$ & & & & & \\
\hline $\mathbf{5}$ & Affective Commitment & -.03 & $.16^{*}$ & .04 & $.59^{* *}$ & $\mathbf{. 7 0}$ & & & & \\
\hline $\mathbf{6}$ & Continuous Commitment & -.08 & .10 & $.17^{*}$ & $.34^{* *}$ & .04 & $\mathbf{. 6 7}$ & & & \\
\hline $\mathbf{7}$ & Normative Commitment & .03 & $.25^{* *}$ & $.16^{*}$ & $.59^{* *}$ & $.49 * *$ & $.30^{* *}$ & $\mathbf{. 6 7}$ & & \\
\hline
\end{tabular}

$\mathrm{N}=211 * * *$ Significance level $<.001, * *$ Significance level $<.01 *$ Significance level $<.05$ Reliabilities $(\alpha)$ given in bold 
Table 3.

\begin{tabular}{|l|c|c|c|}
\hline & \multicolumn{3}{|c|}{ AFFECTIVE COMMITMENT } \\
\hline Predictors & $\boldsymbol{\beta}$ & $\mathbf{R}^{\mathbf{2}}$ & $\Delta \mathbf{R}^{\mathbf{2}}$ \\
\hline Control Variables & & 0.03 & 0.03 \\
\hline Job Involvement & $0.59^{* * *}$ & 0.37 & $0.34 * * *$ \\
\hline
\end{tabular}

$\mathrm{N}=211^{* * *}$ Significance level $<.001, * *$ Significance level $<.01 *$ Significance level $<.05$ Reliabilities $(\alpha)$ given in bold

Table 4.

\begin{tabular}{|l|c|c|c|}
\hline & \multicolumn{3}{|c|}{ CONTINOUS COMMITMENT } \\
\hline Predictors & $\boldsymbol{\beta}$ & $\mathbf{R}^{\mathbf{2}}$ & $\Delta \mathbf{R}^{\mathbf{2}}$ \\
\hline Control Variables & & 0.03 & 0.03 \\
\hline Job Involvement & $0.33^{* * *}$ & 0.14 & $0.11^{* * *}$ \\
\hline
\end{tabular}

$\mathrm{N}=211^{* * *}$ Significance level $<.001, * *$ Significance level $<.01 *$ Significance level $<.05$ Reliabilities $(\alpha)$ given in bold

Table 5 .

\begin{tabular}{|l|c|c|c|}
\hline & \multicolumn{3}{|c|}{ NORMATIVE COMMITMENT } \\
\hline Predictors & $\boldsymbol{\beta}$ & $\mathbf{R}^{\mathbf{2}}$ & $\Delta \mathbf{R}^{\mathbf{2}}$ \\
\hline Control Variables & & 0.07 & 0.07 \\
\hline Job Involvement & $0.56^{* * *}$ & 0.38 & $0.30^{* * *}$ \\
\hline
\end{tabular}

$\mathrm{N}=211^{* * *}$ Significance level $<.001, * *$ Significance level $<.01 *$ Significance level $<.05$ Reliabilities $(\alpha)$ given in bold

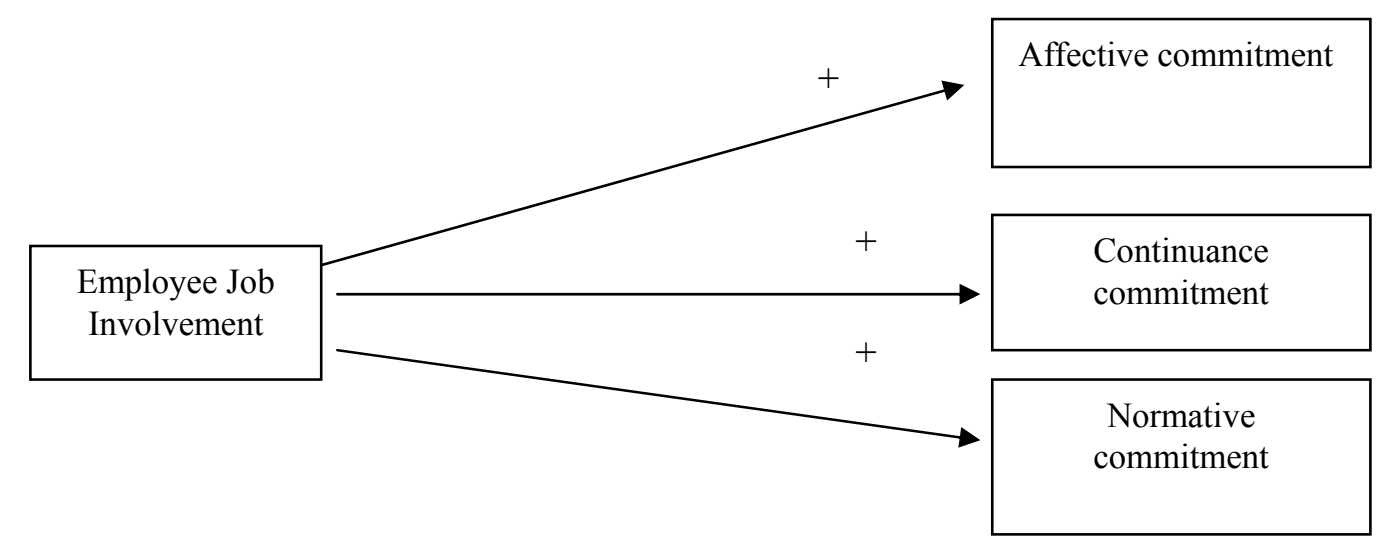

Figure 1. Main model of the effect of Job involvement on Affective commitment, Continuance commitment and Normative commitment 